[Agr. Biol. Chem., Vol. 35, No. 10, p. 1587 1593, 1971]

\title{
Studies on the Fermentative Production and Metabolism of Uridine Coenzymes
}

\author{
Part II. NAD-Dependent UDPGal-4-Epimerase in \\ Torulopsis candida and its Inactivation \\ by 5 '-UMP and Galactose
}

\author{
By Hiroyasu KawAI ${ }^{*}$ and Tatsurokuro TochikURA \\ Department of Food Science and Technology, Kyoto University, Kyoto \\ Received March 27, 1971
}

\begin{abstract}
A partially purified preparation of UDPGal-4-epimerase from lactose-grown Torulopsis candida was found to require exogenous NAD for the full activity, while little activity being observed without NAD. The $K m$ for NAD was $1.4 \times 10^{-4} \mathrm{M}$, showing a relatively low affinity as compared with the enzymes from mammalian sources. The enzyme activity was remarkably inhibited by incubation with 5'-UMP provided that galactose was also present. The concentration of $5^{\prime}$-UMP present seemed more critical than that of galactose on the inhibition; it occurred in the presence of low concentration of 5 -UMP provided that galactose was present enough. The catalytic activity was almost recovered by a short dialysis of the enzyme preparations preincubated with $5^{\prime}$-UMP and galactose. A strong inactivation of the enzyme activity was also found by the combination of 5 -UMP and glucose.
\end{abstract}

Uridine diphosphate galactose-4-epimerase (UDPGal-4-epimerase EG 5.1.3.2) which catalyzes the reversible conversion of UDPGal into UDPG was first found by Leloir in galactose-adapted yeast." The enzyme is found in mammalian system, yeast, bacteria, and plants. ${ }^{2}$ It has been partially purified from calf liver acetone powder, ${ }^{31}$ and highly purified from galactose-adapted Saccharomyces

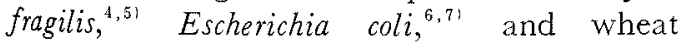
germ. ${ }^{81}$ It has also been reported that the calf liver enzyme has an absolute requirement

* Present address: Department of Food Science, Nara Women's University, Nara.

1) L. F. Leloir, Arch. Biochem., 33, 186 (1951).

2) E.S. Maxwell, "The Enzymes," (P. D. Boyer, H. Lardy and K. Myrbäck, eds.) 2nd Ed. Vol. 1, Academic Press, New York, 1961, p. 443.

3) E. S. Maxwell, J. Biol. Chem., 229, 139 (1957).

4) E. S. Maxwell and H. de R. Szulmajster, ibid., 235, $308(1960)$. for NAD, ${ }^{3)}$ while neither the $S$. fragilis enzyme nor the $E$. coli enzyme requires the presence of NAD added, since the coenzyme binds tightly to the enzyme protein. On the other hand, Kalckar et al. have recently reported that $5^{\prime}$-UMP and specific sugars such as D-galactose, D-fucose and L-arabinose which relate to induction and repression of the biosynthesis of UDPGal-4-epimerase, brought about an enhancement of UDPGal-4-epimerase fluorescence, accompanied by an reductive inactivation of the enzyme obtained from

5) R. A. Darrow and R. Rodstrom, Biochemistry, 7, 1645 (1968).

6) D. B. Wilson and D. S. Hogness, J. Biol. Chem, 239, 2469 (1964).

7) D. B. Wilson and D. S. Hogness, ibid., 244, 2132 (1969).

8) D. Fan and D. S. Feingold, Plant Physiol., 44, 599 (1969). 


\section{S. fragilis, ${ }^{9,101}$}

In the previous article, ${ }^{11}$ it was found that the conversion of UDPGal to UDPG by dried cells of Torulopsis candida was remarkably inhibited by $5^{\prime}-\mathrm{UMP}$ provided that galactose coexisted. This suggested that an inhibition of UDPGal-4-epimerase activity of the yeast took place by the combination of 5'-UMP and galactose. Further investigation on the epimerase showed that a partially purified UDPGal-4-epimerase of $T$. candida required exogenous NAD for the full activity unlike that of $S$. fragilis or $E$. coli. The present paper deals with the nature of the partially purified epimerase of $T$ candida with respect to its NAD dependence. The concerted effects of nucleotides and sugars on enzyme activity were also investigated.

\section{MATERIALS AND METHODS}

Materials. LDPGal, UTP and UDP were prepared by the method reported previously. ${ }^{12,131} 5^{\prime}$-UMP was kindly given by Takeda Chemical Industries, Ltd., and Tanabe Seiyaku Co., Ltd. NAD was obtained from Boehringer and Soehne GmbH, Mannheim. All other chemicals were analytical grade reagents.

Preparation of enyzme. Torulopsis candida IFO 0768 was cultivated on a lactose medium and air-dried as described previously. ${ }^{121}$ UDI $^{2}$ Gal-4-epimerase of the yeast was partially purified as follows. Ten grams of the dried cells were mixed with $20 \mathrm{~g}$ of alumina and $15 \mathrm{ml}$ of $0.1 \mathrm{M}$ potassium phosphate buffer $(\mathrm{pH}$ 7.2), and ground in a cooling mortar for $30 \mathrm{~min}$. It was suspended into $40 \mathrm{ml}$ of the same buffer and was

9) A. U. Bertand II and H. M. Kalckar, Proc. Natl. Acad. Sci, 61, 629 (1968).

10) H. M. Kalckar, A. U. Bertland II and B. Bugge, ibid., 65, 1113 (1970).

11) H. Kawai and T. Tochikura, Agr. Biol. Chem., 35, 1578 (1971).

12) T. Tochikura, K. Kawaguchi, H. Kawai, Y. Mugibayashi and K. Ogata, J. Ferment. Technol,, 46, 970 (1968).

13) T. Tochikura, H. Kawai, S. Tobe, K. Kawaguchi, M. Osugi and K. Ogata, ibid., 46, 957 (1968). subjected to sonication with a $20 \mathrm{Kc}$ Kaijo Denki oscillator at $0 \sim 10^{\circ} \mathrm{C}$ for $15 \mathrm{~min}$. The cell debris was removed by centrifugation at $12,000 \times g$ at $0^{\circ} \mathrm{C}$ for $30 \mathrm{~min}$. The supernatant solution was dialyzed overnight against 2 liters of $0.01 \mathrm{M}$ potassium phosphate buffer ( $\mathrm{pH} \mathrm{7.2)} \mathrm{containing} \mathrm{0.05 \%} \mathrm{2-mercaptoethanol.}$ The cell-free extract $(30 \mathrm{ml})$ was brought to $30 \%$ saturation with solid ammonium sulfate and the precipitate was removed by centrifugation. The precipitate obtained by addition of amnonium sulfate to $600_{0}^{\circ}$ was dissolved in $10 \mathrm{ml}$ of $0.01 \mathrm{M}$ potassium phosphate buffer (pH 7.2) containing $0.05 \%$ 2mercaptoethanol and dialyzed overnight against 2 liters of the same buffer. The dialyzed solution was again brought to $30 \%$ saturation with the salt and the precipitate was discarded. The precipitate obtained by further addition of ammonium sulfate to 60,0 was dissolved in $2 \mathrm{ml}$ of the same buffer and dialyzed overnight against 2 liters of the same buffer. This fraction was used as a partially purified UDPGal4-epimerase throughout this work.

Assay of enzyme activity. UDPGal-4-epimerase activity was assayed by determining the amounts of UDPG formed from UDPGal under the reaction conditions as described in figures and tables. The incubation was carried out at $30^{\circ} \mathrm{C}$, and terminated by immersing the tube in boiling water for $1 \mathrm{~min}$. An aliquot of the supernatant solution was taken to estimate UDPG by UDPG dehydrogenase prepared from acetone powder of bovine liver by the method of Wilson. ${ }^{14}$ The assay condition of UDPG was the same as described previously $y^{13}$ except that $1.5 \mu$ moles of NAD was added in $3 \mathrm{ml}$ of the assay mixture. Protein was estimated by the method of Lowry et al. ${ }^{15}$

\section{RESULTS}

\section{$N A D$ requirement for Torulopsis UDPGal-4- epimerase}

In our preliminary experiment of UDPGal4-epimerase of $T$ candida, it was found that the cell-free extract of the yeast had very weak activity of epimerization of UDPGal to UDPG without addition of NAD. However, the activity was obviously enhanced by the

14) D. Wilson, Anal. Biochem., 10, 472 (1965).

15) O. H. Lowry, N. J. Resebrough, A. L. Farr and R. J. Randall, J. Biol. Chem., 193, 265 (195I). 
addition of exogenous NAD. It has already been reported that the enzyme obtained from calf liver ${ }^{3 \prime}$ has an absolute requirement for $\mathrm{NAD}$ as a coenzyme, whereas those from $S$. fragilis ${ }^{4,5)}$ and $E$. coli $^{6,7)}$ do not require NAD for the activity because NAD binds tightly to their enzyme protein. As is shown in Fig. 1 , the epimerase activity of $T$. candida is highly enhanced by the addition of NAD at the concentration of $4.5 \times 10^{-3} \mathrm{M}$, but little activity was observed without NAD. In the presence of NAD, the equilibrium was attained at about $70 \circ$ UDPG and 309 UDPGal. The result would suggest that the epimerase of $T$. candida, unlike those of $S$. fragilis and $E$. coli, contains loosely-bound NAD to its apoenzyme. The Torulopsis enzyme seems somewhat like that of calf liver ${ }^{31}$ and bovine mammary gland $^{16)}$ which depend on the addition of exogenous NAD for the full activity.

Figure 2 shows the effect of NAD concentration on enzyme activity. The $K m$ for NAD calculated from these data according to the

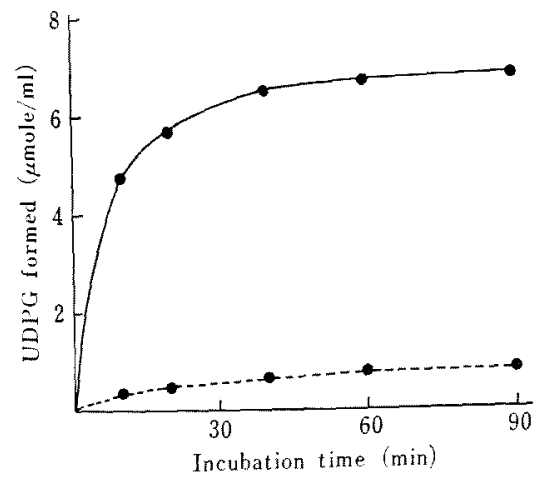

FIG. 1 NAD Requirement for UDPGal-4-Epimerase Activity.

The reaction mixture contained 9.7 , moles of UDPGal, 200 umoles of glycine buffer $(\mathrm{pH} 8.8)$, $2.8 \mathrm{mg}$ of enzyme protein and $4.5 \mu$ moles of $\mathrm{N} A \mathrm{D}$ in a final volume of $1 \mathrm{ml}$. Incubation was carried at $30^{\circ} \mathrm{C}$.

- NAD added,

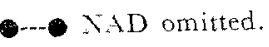

16) C. M. Tsai, N. Holmberg and K. E. Ebner, Arch. Biochem. Biophys, 136, 233 (1970). method of Lineweaver and Burk ${ }^{17 t}$ is $1.4 \times$ $10^{-4} \mathrm{M}$. NAD could not be replaced by NADP,

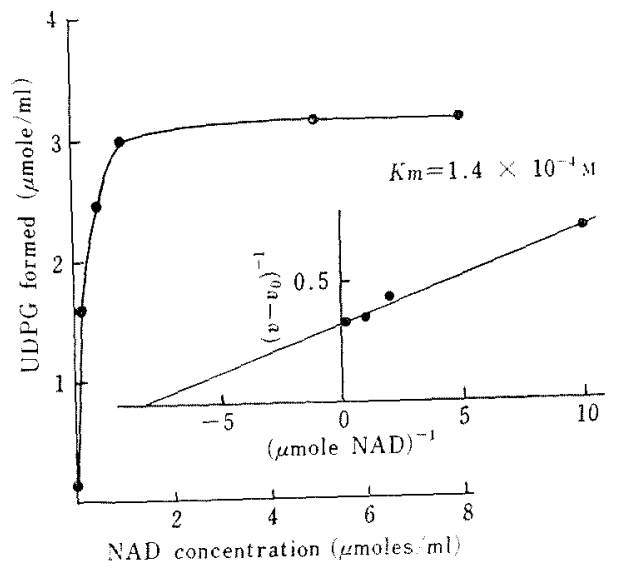

FIG. 2. Effect of NAD Concentration on UDPGal4-Epimerase Activity.

The reaction mixture contained 9.7 pmoles of UDPGal, 200 , moles of glycine buffer ( $\mathrm{pH} 8.8$ ), $1.4 \mathrm{mg}$ of enzyme protein and indicated amounts of $N A D$ in a final volume of $1 \mathrm{ml}$. Incubation was carricd out at $30 \mathrm{C}$ for $15 \mathrm{~min}$.

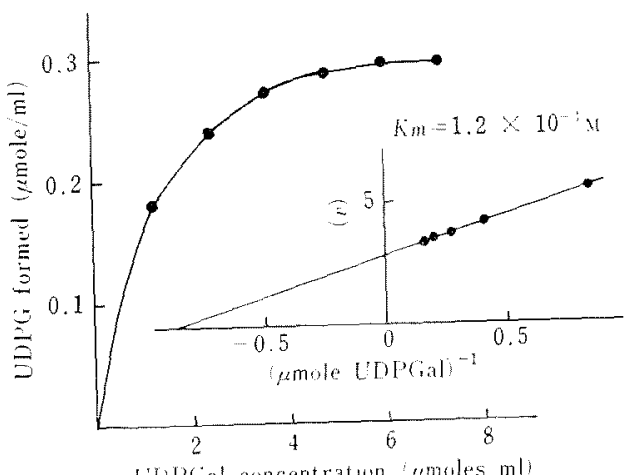

FIG. 3. Fffect of UDPGal Concentration on UDPGalt-Epimerase Activity.

The reaction mixture contained 5 umoles of NAD, 200 , moles of glycine buffer ( $\mathrm{pH} 8.8$ ), $240 \gamma$ of enzyme protein and indicated amounts of UDPGal in a final volume of $1 \mathrm{ml}$. Incubation was carried out at $30^{\circ} \mathrm{C}$ for $10 \mathrm{~min}$.

17) H. Lineweaver and D. Burk, J.Am. Chem. Soc., 56, 658 (1934). 


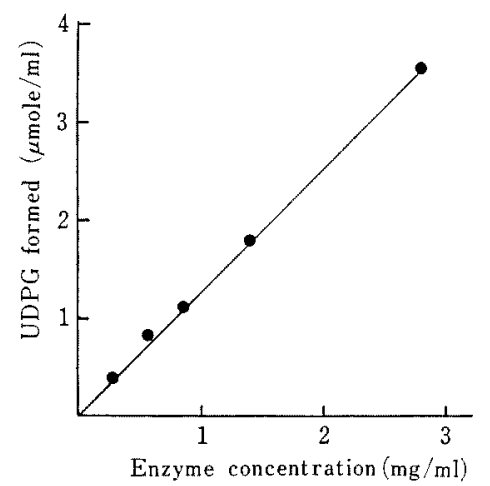

FIG. 4. Effect of Enzyme Concentration on UDPGal4-Epimerase Activity.

The reaction mixture contained $9.7 \mu$ moles of UDPGal, $5 \mu$ moles of NAD, $200 \mu$ moles of glycine buffer $(\mathrm{pH} 8.8)$ and indicated amounts of enzyme in a final volume of $1 \mathrm{ml}$. Incubation was carried out at $30^{\circ} \mathrm{C}$ for $10 \mathrm{~min}$.

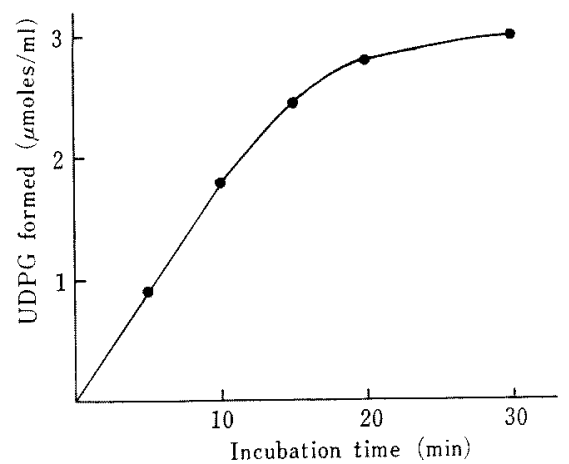

FIG. 5. Effect of Incubation Time on UDPGal-4Epimerase Activity.

The reaction mixture contained 9.7 umoles of UDPGal, $5, \mu$ moles of NAD, $200 \mu$ moles of glycine buffer ( $\mathrm{pH} 8.8$ ) and $1.4 \mathrm{mg}$ of enzyme protein in a final volume of $1 \mathrm{ml}$. Incubation was carried out at $30^{\circ} \mathrm{C}$.

and NADH did not inhibit the epimerase activity at the concentration of $5 \times 10^{-3} \mathrm{M}$. As compared with the enzymes from calf liver and bovine mammary gland ( $K m \mathrm{~s}$ for NAD are $2 \times 10^{-7} \mathrm{M}$ and $5 \times 10^{-7} \mathrm{M}$, respectively), ${ }^{3,16)}$ the Torulopsis enzyme showed relatively low affinity for NAD.
The effect of UDPGal concentration on enzyme activity is shown in Fig. 3. The $K m$ for UDPGal calculated from these data is $1.2 \times 10^{-3} \mathrm{M}$. The linear relationship between amounts of enzyme and UDPG formed during $10 \mathrm{~min}$ of incubation is shown in Fig. 4. The relationship between time of incubation and UDPG formed is shown in Fig. 5. UDPG was increased linearly for about $15 \mathrm{~min}$ incubation.

\section{Inhibition of UDPGal-4-epimerase by $5^{\prime}$-UMP} and galactose

In the previous paper, ${ }^{11 !}$ it was found that the conversion of UDPGal to UDPG by dried cells of $T$ candida was strikingly inhibited by the presence of $5^{\prime}$-UMP and galactose. This observation led to the suggestion that UDPGal4-epimerase of the yeast might be inhibited by the combination of $5^{\prime}$-UMP and galactose, and consequently UDPGal could accumulate in large amounts without being degraded or converted to UDPG under the fermentative condition. It has recently been reported by Kalckar et al. ${ }^{9 !}$ that native epimerase preparations obtained from $S$. fragilis which are specific for NAD are transformed into highly fluorescent reduced form (NADH) of epimerase by addition of 5'-UMP and galactose. The catalytic activity of the reduced epimerase is much lower than that of native epimerase $(10 \sim 15 \%$ of native epimerase) and this reductive inactivation was also found in crude epimerase preparations of $E$. coli, provided that $5^{\prime}$-UMP and galactose are present. ${ }^{101}$ In view of these observations, the effect of $5^{\prime}$. UMP and galactose on the partially purified enzyme preparation of $T$. candida was investigated.

As is shown in Fig. 6, the enzyme activity was remarkably inhibited by incubation with $5^{\prime}$-UMP in the presence of galactose. Although slight inhibition of the activity occurred by addition of either galactose or $5^{\prime}$-UMP, the combination of both brought about a maximum inhibition at the concentration of $1 \times 10^{-2} \mathrm{M}$ 


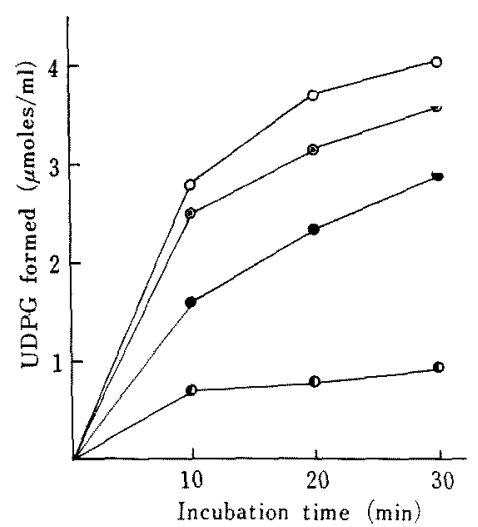

FIG. 6. Effect of 5'-UMP and Galactose on UDPGal4-Epimerase Activity.

The control mixture $(0-0)$ contained 9.7 $\mu$ moles of UDPGal, $5 \mu$ moles of NAD, $200 \mu$ moles of glycine buffer ( $\mathrm{pH} 8.8$ ) and $1.4 \mathrm{mg}$ of enzyme protein in a final volume of $1 \mathrm{ml}$. To the control, were added either 5 -UMP $(10 \mu$ moles $/ \mathrm{ml})$ or galactose $(100 \mu \mathrm{moles} / \mathrm{ml})$ or in combination. They were preincubated with enzyme, NAD and buffer at $30^{\circ} \mathrm{C}$ for $10 \mathrm{~min}$, followed by addition of UDPGal.

○- $\bigcirc$ galactose added,

5'-UMP added, C-C 5'-UMP and galactose added.

$5^{\prime}$-UMP and $1 \times 10^{-1} \mathrm{M}$ galactose. About $25 \%$ of activity of the control was found after 30 min incubation.

The effect of concentrations of $5^{\prime}-\mathrm{UMP}$ and galactose on enzyme activity is shown in Table I. It seems from these data that the concentration of $5^{\prime}$-UMP present is more critical than that of galactose for the inhibition, $5^{\prime}$ UMP concentration at 5 moles per $\mathrm{ml}$ being enough to cause $75 \circ$ inhibition when 100 $\mu$ moles per $\mathrm{ml}$ of galactose coexisted. Taking $5^{\prime}$-UMP concentration of $10 \mu$ moles per $\mathrm{ml}$ as constant, more than 5 times as much galactose as $5^{\prime}$-UMP was necessary to cause $750^{\circ}$ inhibition. That is to say, the inhibition occurs by the presence of a relatively low concentration of $5^{\prime}$-UMP provided that galactose is present enough. These data are also well consistent with those obtained in the previous paper ${ }^{11}$ where the conversion of UDPGal to UDPG by dried cells of the yeast was extremely

\section{TABLE I. EFFECT OF 5'-UMP and GaLactose Concentrations oN UDPGal-4-EpIMERASE ACTIVITY}

The reaction mixture contained $9.7 \mu$ moles of UDPGal, $5 \mu$ moles of NAD, 200 mmoles of glycine buffer ( $\mathrm{pH} 8.8$ ), $1.55 \mathrm{mg}$ of enzyme protein and indicated amounts of $5^{\prime}$-UMP and galactose in a final volume of $1 \mathrm{ml}$. Either 5'-UMP or galactose, or in combination, were preincubated with enzyme, NAD and buffer at $30^{\circ} \mathrm{C}$ for $15 \mathrm{~min}$, followed by the addition of UDPGal and incubated for $30 \mathrm{~min}$.

\begin{tabular}{ccc}
\hline \multicolumn{2}{c}{ Reaction system } & \\
$\begin{array}{c}5 \text {-UMP } \\
\text { added } \\
(\mu \text { moles } / \mathrm{ml})\end{array}$ & $\begin{array}{c}\text { Galactose } \\
\text { added } \\
(\mu \text { moles/ml) }\end{array}$ & $\begin{array}{c}\text { Enzyme activity } \\
(0)\end{array}$ \\
\hline 0 & 0 & 100 \\
10 & 0 & 79 \\
10 & 1 & 71 \\
10 & 5 & 61 \\
10 & 10 & 53 \\
10 & 50 & 27 \\
0 & 100 & 86 \\
0.5 & 100 & 35 \\
1 & 100 & 31 \\
5 & 100 & 25 \\
10 & 100 & 24 \\
15 & 100 & 24 \\
\hline
\end{tabular}

inhibited in the presence of $5^{\prime}$-UMP and galactose. It is an interesting problem whether the epimerase inhibition by $5^{\prime}$-UMP and galactose is reversible or not. As can be seen in Table II, $85.5^{\circ}$ of enzyme activity is recovered by a short dialysis of the enzyme preparations preincubated with $5^{\prime}$-UMP ( 2 \% $\left.10^{-2} \mathrm{M}\right)$ and galactose $\left(2 \times 10^{-1} \mathrm{M}\right)$, whereas only about $50 \%$ of activity is retained without dialysis. However, a strong inhibition was observed again by incubation with additional $5^{\prime}$-UMP and galactose to the preincubateddialyzed enzyme. These observations suggest that the inhibition of epimerase by $5^{\prime}$-UMP and galactose may probably be reversible and perhaps these inhibitors bind loosely to enzyme protein.

The inhibitory effect on enzyme activity was further investigated using UDP, UTP 
TABLE II. REversibility OF UDPGal-4-EPIMERASE INHIBITION BY 5'-UMP AND GALACTOSE

The incubation mixture contained $9.7 \mu$ moles of UDPGal, 5 tmoles of NAD, $200 \mu$ moles of glycine buffer ( $\mathrm{pH} 8.8$ ), and $3.25 \mathrm{mg}$ of enzyme protein in a final volume of $1 \mathrm{ml}$. The incubation was carried out at $30^{\circ} \mathrm{C}$ for $30 \mathrm{~min}$. The preincubation of enzyme in the Exp. (2), (3) and (4) was carried out at $30^{\circ} \mathrm{C}$ for $30 \mathrm{~min}$ by adding $5^{\prime}$-UMP $\left(2 \times 10^{-2} \mathrm{M}\right)$ and galactose $\left(2 \times 10^{-1} \mathrm{M}\right)$ to enzyme solution. An aliquot of preincubated enzyme was dialyzed at $4^{\circ} \mathrm{C}$ for $3 \mathrm{hr}$ against $0.01 \mathrm{M}$ potassium phosphate buffer ( $\mathrm{pH} 7.2$ ) containing $0.05 \%$ 2-mercaptoethanol. To the dialyzed enzyme, 5'LMP (20 rmoles) and galactose (200 umoles) were added again and incubated in the Exp. (4).

\begin{tabular}{|c|c|c|c|}
\hline $\begin{array}{l}\text { Exp. } \\
\text { No. }\end{array}$ & $\begin{array}{l}\text { Treatment of enzyme } \\
\text { preparations }\end{array}$ & $\begin{array}{l}\text { Enzyme } \\
\text { oncentra- } \\
\text { tion } \\
\text { (mg) }\end{array}$ & $\begin{array}{l}\text { Enzyme } \\
\text { activity } \\
(90)\end{array}$ \\
\hline (1) & $\begin{array}{l}\text { Not preincubated with } 5^{\prime} \text {-UMP } \\
+ \text { galactose }\end{array}$ & P 3.25 & 100 \\
\hline$(2)$ & $\begin{array}{l}\text { Preincubated with } 5^{\prime} \text {-UMP+ } \\
\text { galactose at } 30^{\circ} \mathrm{C} \text { for } 30 \mathrm{~min}\end{array}$ & 3.25 & 49.4 \\
\hline (3) & $\begin{array}{l}\text { Preincubated with } 5^{\prime} \text {-UMP+ } \\
\text { galactose at } 30^{\circ} \mathrm{C} \text { for } 30 \mathrm{~min} \text {, } \\
\text { and dialyzed }\end{array}$ & 3.25 & 85.5 \\
\hline$(t)$ & $\begin{array}{l}\text { Preincubated with } 5^{\prime}-\mathrm{UMP}+ \\
\text { galactose at } 30^{\circ} \mathrm{C} \text { for } 30 \mathrm{~min}, \\
\text { and dialyzed. 5'-U.MP and } \\
\text { galactose were added again } \\
\text { to the enzyme }\end{array}$ & $\mathrm{d} 3.25$ & 18.2 \\
\hline
\end{tabular}

and glucose other than 5'-UMP and galactose. As is shown in Fig. 7, a strong inhibition is also observed by incubating enzyme with 5 'UMP in the presence of glucose instead of galactose. On the other hand, when 5'-UMP is replaced by UDP or UTP and incubated with galactose or glucose, a slight inhibitory effect was observed, but it became to lower in the order of the combinations with UDP+ hexoses and UTP + hexoses.

\section{DISCLSSION}

Evidence obtained in a number of laboratories has shown that the UDPGal-4-epimerase obtained from various sources requires NAD as a cofactor. The enzymes isolated from mammalian sources require a catalytic amount

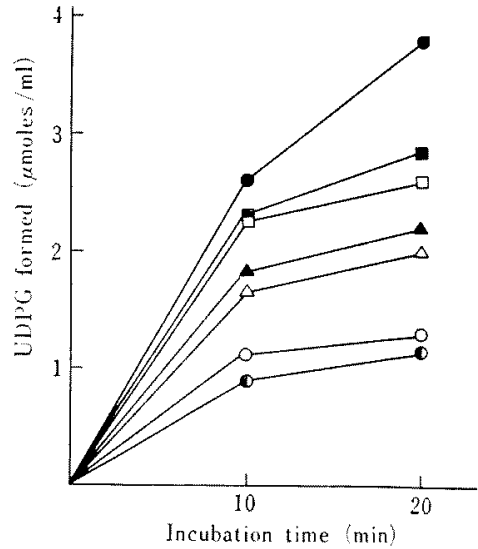

FIG. 7. Effect of Nucleotides and Sugars on UDPGal4-Epimerase Activity.

The control mixture (-) contained $9.7 \mu$ moles of UDPGal, $5 \mu$ moles of NAD, $200 \mu$ moles of glycine buffer $(\mathrm{pH} 8.8$ ) and $1.55 \mathrm{mg}$ enzyme protein in a final volume of $1 \mathrm{ml}$. To the control, nucleotides (each $10 \mu \mathrm{moles} / \mathrm{ml}$ ) and sugars (each $100 \mu \mathrm{moles} / \mathrm{ml})$ were added in combination indicated below. They were preincubated with enzyme, NAD and buffer at $30^{\circ} \mathrm{C}$ for $15 \mathrm{~min}$, followed by addition of UDPGal.

- UTP + galactose, $\square-\square \mathrm{UTP}+$ glucose,

$\Delta$ - $\Delta$ UDP + galactose, $\Delta-\triangle \mathrm{LDP}+$ glucose,

- $5^{\prime}$-UNP + galactose,

O-O 5'-UMIP + glucose.

of added NAD for the reaction, ${ }^{3,16)}$ whereas those from $S$. fragilis and $E$. coli do not require exogenous NAD, which binds tightly to their enzyme protein. ${ }^{4,6)}$ The present study showed that a partially purified epimerase from Torulopsis candida grown on a lactose medium was highly stimulated by the addition of exogenous NAD for the full activity. The $K m$ for NAD of the yeast enzyme $\left(1.4 \times 10^{-4} \mathrm{M}\right)$ was higher than those of calf liver $\left(2 \times 10^{-7} \mathrm{M}\right)$ and bovine mammary gland $\left(5 \times 10^{-7} \mathrm{M}\right)$. It appears likely that the Torulopsis enzyme contains loosely-bound NAD in its apoenzyme, unlike those from $S$. fragilis and $E$. coli. However, further investigation should be performed to clarify whether the yeast enzyme does really contain NAD in its native protein. The observation that the activity of the yeast 
epimerase undergoes a strong inhibition by incubation with $5^{\prime}$-UMP and galactose would suggest that different structural forms of the enzyme may exist as has been observed in the purified epimerase from $S$. fragilis in the presence of $5^{\prime}$-UMP and certain specific sugars." Kalckar et al. ${ }^{101}$ have reported that native enzyme preparations from $S$. fragilis was largely composed of NAD-epimerase with only $150^{\circ}$ to $20 \%$ in the form of fluorescent NADH-epimerase. The addition of 5 -UMP and galactose was found to transform the epimerase into the highly fluorescent reduced form $(\mathrm{NADH})$ of epimerase which was in an inactive state. They assumed that this inactivation of the reduced enzyme might be due to the reduced state of the prosthetic group brought about by the substrate analogues such as $5^{\prime}$-UMP and galactose, and might be due to an alterations of the protein conformation. ${ }^{101}$ It is assumed that the inactivation of the Torulopsis enzyme may possibly be brought about in a similar way as was observed in the Saccharomyces enzyme. This aspect will be investigated with more purified enzyme preparations in the near future. The present investigation will also strongly support the consideration in the previous paper ${ }^{11}$ that the efficient accumulation of UDPGal from $5^{\prime}$ UMP and galactose by dried cells of $T$. candida may result from the specific inhibition of UDPGal-4-epimerase activity by the fermentation substrates, 5'-UMP and galactose, under the reaction condition. 